\title{
Role of xylem parenchyma in maintaining the water balance of trees
}

\author{
T. J. WODZICKI and C. L. BROWN*
}

A survey of various taxonomical groups of woody plants brings to ones attention the increasing amount and variety of living components of woody stems in the course of evolution. For example, from the nearby exclusively ray parenchyma in the xylem of conifers, various types of xylem parenchyma have evolved in association with the large conducting vessel elements in hardwood species. The percentage of xylem parenchyma may constitute as much as 40 per cent of the xylem of some deciduous trees. The possible role of living cells in water transport has attracted the attention of plant physiologists for many years, however, none of the so called ,vital theories" proposed by earlier authors (G o d l e w s k i 1884; B o s e 1923; M o lis h 1929), have been proved and accepted. The role of the living component of xylem in the physiology of trees is poorly understood and in the absence of more systematic studies it is assumed to be associated mainly with storage functions. The present experiments were designed to study the role of xylem parenchyma in the water regime of trees, using alive and killed stems.

In preliminary experiments, $70 \mathrm{~cm}$ stem segments of 2-year-old sycamore (Platanus occidentalis L.) were rapidly killed by various methods (70\% ethyl alcohol, $1 \%$ potassium cyanide, $1 \%$ picric acid, diethyl ether vapour, autoclaving under water, or dry autoclaving) to compare the rates and amount of water movement between alive and dead stems. Without exception, the rate of water movement was faster in alive stem segments.

To determine what effect the sheath of living tissues exterior to the functional xylem (i.e., cambium and inner bark) might have on water movement in stems, the bark including the cambium was completely removed and the stems immediately wrapped in plastic tape along their entire length to prevent evaporation from the exposed xylem surface. The rate of water translocation was determined by using an aqueous solution of acid fuchsin $(500 \mathrm{ppm})$ in alive and poisoned stems, with and without

* Department of Forest Botany, Agricultural University of Warsaw, Poland, and School of Forestry, University of Georgia, Athens, Georgia, U.S.A. 
bark. Stems were sectioned at $175 \mathrm{~mm}$ intervals at the end of each experiment and the intensity and area of stained xylem determined in comparable units. The rate of water translocation in alive stems with and without bark was faster and the amount of stain accumulated was greater than in the dead ones (Table 1). In all additional experiments, the treated stems were poisoned using diethyl ether vapor in a closed container for a standard period of 24 hours. This technique permitted the use of stems possessing different degrees of water stress (dehydration) at the beginning of successive experiments.

Table 1

Rate of transport and relative amount of water in alive and dead segments of Platanus occidentalis $\mathrm{L}$.

\begin{tabular}{|c|c|c|c|c|c|c|c|c|}
\hline Treatments * & Bark & $\begin{array}{l}\text { Per cent } \\
\text { stem } \\
\text { hydration } \\
\text { at } \\
\text { beginning }\end{array}$ & $\begin{array}{c}\text { Rate } \\
\text { of } \\
\text { transloc. } \\
\text { hrs. min. }\end{array}$ & $\begin{array}{l}\text { Accum. } \\
\text { of dye } \\
\text { after } \\
48 \text { hrs. }\end{array}$ & $\begin{array}{l}\text { Per cent } \\
\text { stem } \\
\text { hydration } \\
\text { at } \\
\text { beginning }\end{array}$ & \multicolumn{2}{|c|}{$\begin{array}{c}\text { Rate } \\
\text { of } \\
\text { transloc. } \\
\text { hrs. min. }\end{array}$} & $\begin{array}{c}\text { Accum. } \\
\text { of } \\
\text { dye } \\
\text { after } \\
48 \text { hrs. }\end{array}$ \\
\hline \multirow[t]{2}{*}{ Alive } & + & 93.5 & $27 \quad 08$ & $37^{* *}$ & 81.7 & 0 & 46 & $66^{* *}$ \\
\hline & - & 95.2 & $29 \quad 08$ & 35 & 81.2 & 1 & 39 & 63 \\
\hline \multirow[t]{2}{*}{ Ether } & + & 96.7 & no signs after & 12 & 81.2 & 1 & 32 & 36 \\
\hline & - & 97.0 & 48 hours & 8 & 83.0 & 1 & 30 & 37 \\
\hline \multirow[t]{2}{*}{$\mathrm{KCN}$} & + & 92.8 & , , & 14 & 86.1 & 16 & 52 & 43 \\
\hline & - & 93.5 & & 6 & 85.1 & 17 & 28 & 34 \\
\hline \multirow[t]{2}{*}{$\mathrm{KCN}$} & + & 88.7 & , , & 22 & - & - & - & - \\
\hline & - & 90.3 & & 20 & - & - & - & - \\
\hline
\end{tabular}

- Each treatment consisted of 3 sticks $-70 \mathrm{~cm}$ long.

** Difference in accumulation of dye in alive and poisoned tissue are highly significant, and reflect total amoun of water absorbed.

The uptake and evaporation of water by stems were measured gravimetrically in subsequent experiments using one meter long stem segments of 2-ýear-old Platanus occidentalis L. and Pinus densiflora Sieb. and Zucc., one-year-old Populus deltoides (Cast.) Sud., and three-year-old Fraxinus americana $\mathrm{L}$. These experiments again showed significantly greater amount of water accumulated by alive stems of all species during the first 24 hours of water uptake (Table 2). These differences were still maintained at a significant level after 48 hours, although during the latest 24 hours the rate of water accumulation greatly decreased in both dead and alive stems and in Populus and Fraxinus it even showed a reversed relation. Three of the investigated species: Platanus, Populus, and Fraxinus, showed significantly greater evaporation of water from the cut surface of stems as measured after 48 hours. At the surface of alive pine stems the exuded layer of resin probably prevented higher rates of evaporation as compared with dead stems whose cut surface was generally free of resin due to the ether treatment. 


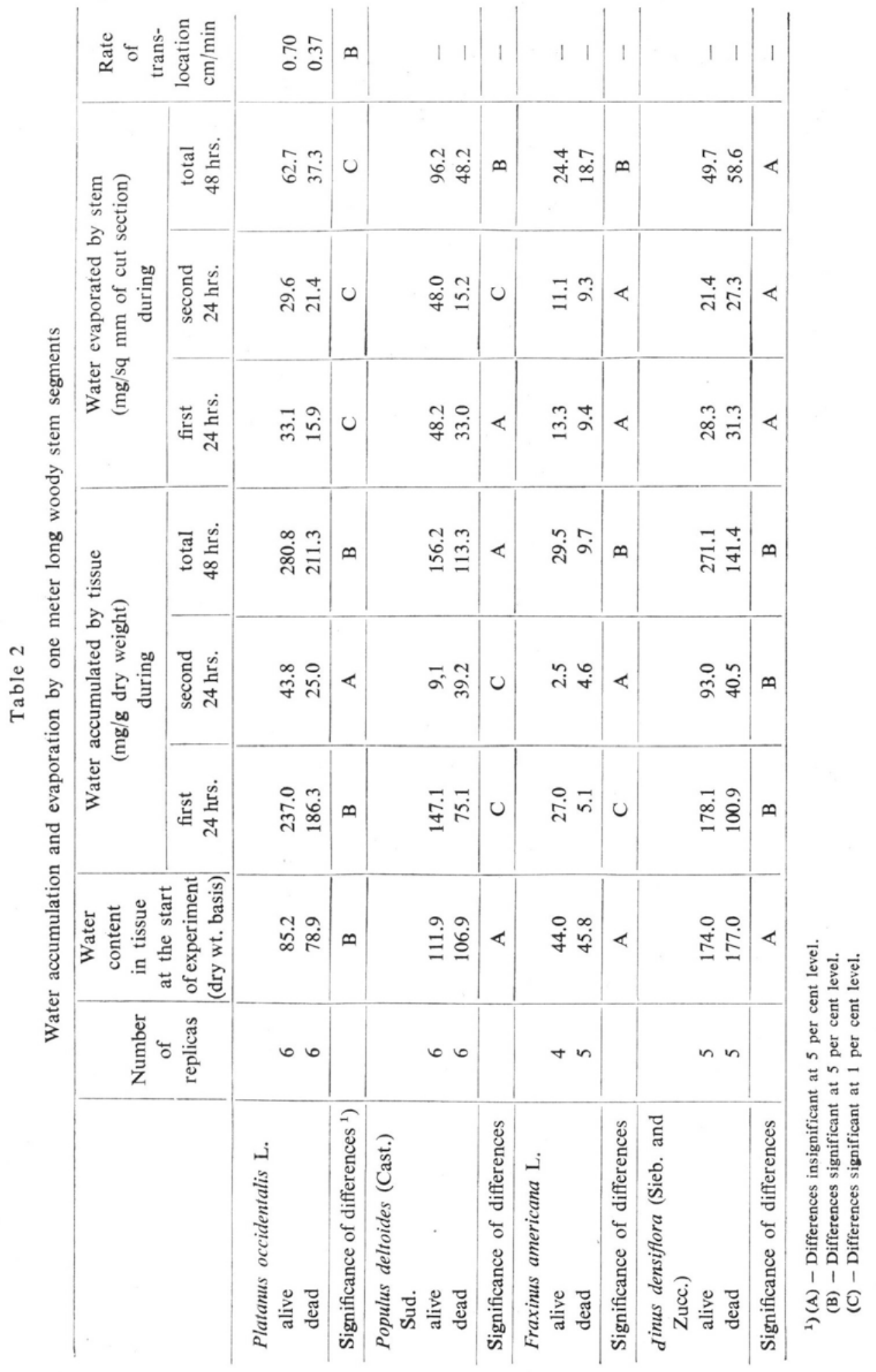


A third experiment was performed in the forest using $10 \mathrm{~m}$ tall trees of Platanus occidentalis L. Twenty trees were cut in early morning and allowed to transpire during the next four hours. After this period the crowns were removed at a distance of $6.2 \mathrm{~m}$ from the base and the bark was removed from the uppermost $20 \mathrm{~cm}$ of each stem to provide a larger surface for evaporation. Ten stems were placed in solid aluminium pipes and etherized for 24 hours. Control stems were protected against further loss of water by wrapping them in thick polyethylene sheets. After this 24 hour period, stems of both series were carefully wrapped in a continuous sheet of aluminum foil sealed with gummed tape all along their length except the uppermost $20 \mathrm{~cm}$, which was allowed to evaporate freely into the atmosphere. Stems were placed vertically with their basal ends in four liter plastic containers protected against loss of water by evaporation from the water surface. Stems were weighed at the beginning and the end of each 24 hour period during the three day experiment. The volume of water in each container was measured at the same intervals. The data in Table 3 also show that the uptake and accumulation of water during 24 hours in alive stems was significantly greater than in the treated ones, and these differences persisted over a period of 48 hours.

Table 3

Water accumulation and evaporation by six-meter long Platanus occidentalis L. stems

\begin{tabular}{c|c|c|c|c|c}
\hline \multirow{2}{*}{$\begin{array}{c}\text { Hours } \\
\text { of water } \\
\text { absorption }\end{array}$} & $\begin{array}{c}\text { Number } \\
\text { of } \\
\text { stems }\end{array}$ & \multicolumn{2}{|c|}{$\begin{array}{c}\text { Water accumulated in stem } \\
\text { (mg/g fresh wt.) }\end{array}$} & \multicolumn{2}{|c}{ Water evaporated per stem } \\
\cline { 3 - 5 } & alive & etherized & alive & etherized \\
\hline 24 & 10 & $21.9^{*}$ & 15.0 & 78.8 & 60.6 \\
48 & 5 & $24.7^{*}$ & 17.8 & 126.6 & 110.6 \\
72 & 5 & 30.7 & 27.0 & 185.8 & 153.8 \\
\hline
\end{tabular}

* Difference between amount of accumulated water by alive and etherized stems after 24 and 48 hours is significant $P \geqslant 0.05$.

Almost all of the serious objections to the cohesion-transpiration theory of water movement in trees as formulated by Dix on (1914) have been overcome in recent years ( $\mathrm{S} \mathrm{ch} \mathrm{ol} \mathrm{and} \mathrm{e} \mathrm{r} \mathrm{1958;} \mathrm{Z} \mathrm{i} \mathrm{m} \mathrm{m} \mathrm{e} \mathrm{r} \mathrm{m} \mathrm{a} \mathrm{n} \mathrm{n}$ 1964), and most physiologists now regard longrange water transport in trees as a purely physical phenomena occurring through dead xylem elements by tensions created in transpiring leaves. In elaborating the cohesion theory of water movement, practically all attention has been focused on the energy requirements and mechanical forces involved in lifting water columns to great heights in forest trees. Little significance has been attached to the beneficial influences of living xylem cells, or indeed, to the probable necessity of such cells in maintaining the system which makes possible the continued movement of water by the cohesion-transpi- 
ration mechanism in land plants. The cohesion theory of water movement as now formulated requires only a living sheath of inner bark surrounding the xylem to prevent the dead transporting elements from ,,drying out" and thus becoming permanently embolized by excessive water loss to the atmosphere. It is known that high rates of transpiration during the day creates water deficits (dehydration) throughout the stems and roots of plants which are partially or completely satisfied by nocturnal rehydration when losses from evaporation are at a minimum. Because the water conducting elements of the xylem are in imminent contact with the living symplast throughout the plant it is only logical that the suction forces of myriads of living cells bring about more rapid rehydration and redistribution of water than could be accomplished by the purely physical forces of diffusion and imbibition in cellulose cell walls. The results of our present experiments with several diverse species support this hypothesis, and it is seen that both the rate and intensity of water transport is greater in alive than in dead or narcotized stems. This explanation seems adequate to account for the relatively rapid rates of water movement in completely decapitated trees where evaporation from the cut surfaces was prevented ( $\mathrm{Gr}$ e e nidg e 1958), although the possible role of root pressure in these studies was not completely excluded.

Even though much more research needs to be done on the role of living cells in maintaining the water balance of trees, it appears that the cohesion-transpirational forces operating during successive diurnal cycles can be maintained indefinitely only when alternating with the often obscure but equally important functions of living cells.

\section{Department of Forest Botany}

Agricultural University of Warsaw,

Warsaw, ul. Rakowiecka 26/30.

(Entered: February 20, 1970)

\section{REFERENCES}

B o s e Y. C., 1923, The Physiology of the Ascent of Sap, Longmans, Green \& Co. Inc., London.

D i x o n H. H., 1914, Transpiration and the Ascent of Sap in Plants, The Macmillan Co., London.

G odlew s ki E., 1884, Jahrb. wiss. Bot. 15, 569.

Greenidge, K.N.H., 1958, [in:] The Physiology of Forest Trees, (Thimann, K.V.ed). Ronald Press Co., N.Y.

Molis h H., 1929, Science 69, 217.

Scholander P. F., 1958, [in:] The physiology of forest trees, (Thimann, K.V. ed). Ronald Press Co., N.Y.

Zimmermann M. H., 1964, [in:] The State and Movement of Water in Living Organisms, Cambridge University Press, London. 


\section{Rola miękiszu drzewnego w utrzymywaniu bilansu wodnego drzewa}

\section{Streszczenie}

Rola żywego miękiszu drzewnego w życiu drzewa jest mało poznana i wobec braku poważniejszych studiów, miękiszowi przypisuje się głównie funkcje tkanki zapasowej. Możliwość, że miękisz drzewny spełnia istotną rolę w procesie transportu wody sugerowana przez różnych autorów (G o dlew s ki 1884, B o s e 1923, M olis h 1929) nie znalazła w dotychczasowej postaci potwierdzenia w wynikach badań i nie zyskała poparcia współczesnych badaczy. Przedstawiona obecnie praca ukazująca wyniki wstępnych doświadczeń miała na celu przedstawienie tej sprawy w nowym świetle. Badano szybkość przewodzenia i ilość pobranej wody przez odcinki pędu kilku gatunków drzew leśnych. Odcinki te uprzednio poddawano działaniu kilku czynników mających na celu wyłączenie lub zmianę czynności komórek miękiszu drzewnego. Wykorzystując uzyskane wyniki przeprowadzono krótką dyskusję wskazując na możliwość udziału miękiszu drzewnego w procesie rehydracji pnia w ciągu nocy, umożliwiającym szybkie zlikwidowanie deficytu wodnego w pniu powstałego w wyniku intensywnej transpiracji rośliny w czasie dnia. 